\title{
Perlindungan buruh migran Indonesia melalui deteksi dini HIV/AIDS pada saat reintegrasi ke daerah asal
}

\section{The protection of Indonesian migrant workers through early detection of HIVIAIDS at the time of reintegration into the place of origin}

\author{
Sri Endah Kinasih'1, Vinsensio M.A. Dugis² \\ ${ }^{1}$ Departemen Antropologi, FISIP, Universitas Airlangga \\ ${ }^{2}$ Departemen Hubungan Internasional, FISIP, Universitas Airlangga \\ Jalan Airlangga 4-6 Surabaya 60286, Indonesia. \\ Telephone: +62 315011744 \\ E-mail: kinasih_unair@yahoo.com
}

\begin{abstract}
As the number of Indonesian Migrant Workers seems to increasing every year, the issue regarding their protection is equally important. The Indonesian government's existing protection mechanism seems to still lack behind compared to the increasing needs of proper protection steps especially the ones that related to the issue of early detection for HIV/AIDS. The existing regulation of the Head of BNP2TKI No.01/KA/SU/1/2008 is still far from effective at the implementation level. This study examines various healt issues countered by migrant workers before they depart and after they arrive back to Indonesia. To what extent the role of relevant authorities have provide a proper early detection to various health problems experienced by the migrant workers, especially on the issue of HIV/AIDS? It has found that the overall protection mechanism is till far from what is expected, including an early detection mechanism for HIV/AIDS. There is an urgent need on the government side to improve the mechanism and increasing coordination between related departments is a must. Failure to fulfill this could trigger a wider impact as the transmission of HIV/AIDS then may pass on to the family or wider society at the place of origin of the migrant workers. Data collection includes the steps of observation, in-depth interviews, gathering information through informants are individuals who have the knowledge and experience of the problems studied, and the next process is the classification and identification of data based on the theme for the next analysis.
\end{abstract}

Keywords: early detection, migrant protection, migrant workers, poverty

\begin{abstract}
Abstrak
Ketika jumlah Buruh Migran Indonesia (BMI) setiap tahunya terus meningkat, isu yang berkaitan dengan perlindungan mereka juga tak kalah pentingnya. Mekanisme perlindungan yang saat ini dipunyai oleh pemerintah Indonesia nampaknya ketinggalan dibandingkan dengan peningkatan jumlah langkah-langkah perlindungan yang baik, terutama yang berkaitan denga isu deteksi dini HIV/AIDS. Regulasi BNP2TKI No.01/KA/SU/1/2008, masih jauh dari efektif pada tingkat implementasinya. Studi ini menelaah berbegai isu kesehatan yang dihadapi BMI sebelum mereka berangkat dan setelah mereka kembali ke Indonesia. Seberapa jauh peran dari otoritas-otoritas dan dinas-dinas terkait telah memberikan deteksi dini yang baik terhadap berbagai problem kesehatan yang dialami para pekerja migrant, terutama yang berkaitan dengan isu HIV/AIDS? Penelitian menemukan bahwa secara umum mekanisme perlindungan yang ada masih jauh dari yang diharapkan, termasuk mekanisme deteksi dini untuk HIV/AIDS. Ada kebutuhan mendesak di pihak pemerintah untuk memperbaiki mekanisme yang ada dan meningkatkan koordinasi antar dinas-dinas terkait merupakan suau keharusan. Jika gagal memenuhi ini, maka dampak yang lebih luas dapat terjadi, sebab proses transmisi penyakit HIV/AIDS dapat berlangsung tanpa control kepada keluarga atau masyarakat di wilayah asal para pekerja migrant. Pengumpulan data yang meliputi langkah observasi, wawancara mendalam, pengumpulan informasi melalui informan yang merupakan individu-individu yang memiliki pengetahuan dan pengalaman tentang permasalahan yang diteliti, dan proses selanjutnya adalah klasifikasi dan identifikasi data berdasarkan tema untuk selanjutnya dianalisis.
\end{abstract}

Kata kunci: deteksi dini, perlindungan migran, pekerja migran, kemiskinan 


\section{Pendahuluan}

Perlindungan terhadap Buruh Migran Indonesia (BMI) hingga saat ini masih menjadi salah satu isu penting yang perlu mendapatkan perhatian dari banyak pihak, terutama pemerintah. Persoalan keadilan yang meliputi banyak aspek bagi para BMI masih sangat membutuhkan perhatian serius (Farbenblum, Taylor-Nicholson, Paoletti 2013). Rendahnya koordinasi antar departemen terkait dalam pemerintahan di dalam penanganan BMI kerap menjadi salah satu faktor pemicu belum optimalnya penanganan masalah BMI (Azmy 2011). Selain karena menjadi salah satu indikasi adanya kemiskinan, peningkatan jumlah BMI berkorelasi dengan peningkatan jumlah penduduk miskin. Di titik ini, kehadiran BMI berfungsi positif sebagai salah satu jalan keluar mengatasi fenomena kemiskinan (Sugiyarto \& Vargas-Silva 2012), meskipun belum tentu menjadi pilihan jalan keluar terbaik (McCulloch, Timmer, Weisbrod, 2007). Koesrianti (2010) menyatakan bahwa buruh migran ada di hampir semua sektor perekonomian dan mereka memberikan kontribusi terhadap pertumbuhan ekonomi baik bagi negara asal (home state) maupun bagi negara tujuan bekerja (host state). Karena itu, tidak jarang predikat pahlawan-pahlawan ekonomi (economic heroes) atau pahlawan devisa juga diberikan kepada meraka (Setyawati 2013). Namun demikian, berbagai resiko mulai dari masalah hukum (Sefriani 2013), kesehatan hingga keselamatan tidak terelakkan dihadapi oleh para BMI, termasuk di dalamnya resiko tertular penyakit HIV/AIDS (Hugo 2001).

Sebagaimana dipaparkan pada bagian pembahasan artikel ini, Propinsi Jawa Timur selain merupakan salah satu propinsi dengan jumlah kabupaten/kota asal BMI terbanyak, juga menduduki ranking kedua setelah DKI dalam kasus HIV/AIDS, dimana dalam hal ini ditengarai salah satu faktor penyebabnya adalah dampak dari Buruh Migran Perempuan (BMP) yang kembali dari negara tujuan tempat mereka bekerja. Untuk itulah maka upaya deteksi dini terhadap BMP menjadi krusial sebelum proses reintegrasi ke daerah asalnya.

Oleh karena itu, menjadi penting untuk mencermati aktivitas yang dilakukan pihak-pihak terkait di bandara dan pelabuhan ketika proses pemberangkatan dan sebagai sebagai "pintu pertama" reintegrasi BMP ketika mereka kembali dari negara tujuan. Sebab tahapan ini dimaksudkan sebagai upaya utama mencegah berbagai persoalan yang berkaitan dengan buruh migrant (Yazid 2013). Maka pertanyaannya adalah, apa saja permasalahan kesehatan yang dialami BMP sebelum dan setelah kembali dari negara tujuan? Sejauhmana peran yang dilakukan petugas di Gedung Pendataan Kepulangan Khusus Tenaga Kerja Indonesia (GPKTKI) dan fungsi dinas-dinas terkait telah memberikan bentuk perlindungan kepada BMP ketika menerima laporan masalah kesehatan dari BMP? Jawaban atas pertanyaan-pertanyaan ini, memperlihatkan potret umum kondisi perlindungan BMP terkait deteksi dini HIV/AIDS pada saat pemberangkatan maupun kepulangan ke Indonesia.

Deteksi dini dirancang untuk mengidentifikasi suatu penyakit secara dini. Hal tersebut memungkinkan intervensi dini dan pengaturan dengan harapan dapat menurunkan mortalitas dan penderitaan yang diakibatkan dari suatu penyakit. Deteksi dini ini sangat penting untuk diagnosis lebih awal bagi kepulangan buruh migran perempuan ketika berada di GPKTKI, karena pemerintah tidak tahu kondisi pekerjaan maupun perbuatan yang pernah dilakukan di negara tujuan. Beban kerja di negara tujuan memiliki dampak yang cukup signifikan terhadap situasi kesehatan pasca kepulangan kembali dan tiba kembali di desa. Penelitian LPKP (2010) menunjukkan pasca kepulangan banyak buruh migran yang mengalami gangguan kesehatan, diantaranya mengalami tekanan psikologi, penyakit kulit kronis akibat seringnya bersentuhan dengan bahan-bahan permbersih yang terbuat dari bahan kimia keras dan penyakit dalam seperti liver dan paru-paru. Belum lagi bagi buruh migran perempuan yang mendapat perlakukan fisik (penganiayaan) maupun seksual (seperti pemerkosaan). Demikian juga buruh migran perempuan yang bekerja sebagai pekerja seks. Penyakit HIV/AIDS, paru-paru, jantung, ginjal, hepatitis dan sebagainya sampai pada kehamilan yang tidak diinginkan, lepas dari medical screening. 


\section{Metode Penelitian}

Data diambil dari proses penelitian yang dilakukan pada tahun 2014 di dua belas kota/kabupaten di Propinsi Jawa Timur, dengan pertimbangan bahwa propinsi ini adalah pengirim jumlah BMP terbanyak. Disamping itu, kedua belas kota/kabupaten terpilih ini telah secara serius mengkaji disusunnya sebuah peraturan daerah tentang penanggulangan HIV/AIDS yang lebih konkrit. Untuk itu, dalam rangka mendapatkan data dan informasi yang lebih empirik, penelitian menggunakan jenis penelitian deskripstif dengan pendekatan kualitatif, yang dilakukan melalui beberapa tahapan.

Pada tahap awal, lokasi penelitian ditentukan secara purposive yaitu di kota/kabupaten Malang, Ponorogo, Blitar, Banyuwangi, Tulungagung, Madiun, Kediri, Bangkalan, Magetan, Jember, Trenggalek, dan Ngawi. Adapun pertimbangan pemilihan lokasi ini, selain dua poin yang telah disebutkan sebelumnya, juga memperhitungkan kenyataan bahwa Peraturan Kepala BNP2TKI No. Per.01/KA/Su/1/2008 yang mengatur tahapan pada proses pemberangkatan dan reintegrasi BMI di Propinsi Jawa Timur, nampaknya belum mampu membuat prosedur yang tepat untuk menentukan kuantitas dan kualitas akses dan informasi bagi BMI.

Tahapan berikutnya ialah pengumpulan data yang meliputi langkah observasi, wawancara mendalam, pengumpulan informasi melalui informan yang merupakan individu-individu yang memiliki pengetahuan dan pengalaman tentang permasalahan yang diteliti, dan proses selanjutnya adalah klasifikasi dan identifikasi data berdasarkan tema untuk selanjutnya dianalisis.

\section{Jawa Timur \& fenomena HIV/AIDS}

Masih tingginya angka kemiskinan adalah salah satu alasan munculnya kebijakan pemerintah tentang pengiriman buruh migran ke luar negeri. Sejak sekitar tahun 1970-an, pemerintah Indonesia telah membuka diri dengan mengirimkan pekerja migran ke luar negeri melalui program Angkatan Kerja Antar Negara (Pitoyo 2010: 397).

Provinsi Jawa Timur adalah salah satu provinsi yang terbesar sebagai daerah asal Buruh Migran Indonesia (BMI), seperti terlihat pada tabel 1. Dari tabel ini terlihat bahwa terdapat 12 kabupaten di Jawa Timur yang warganya banyak memilih menjadi Buruh Migran Indonesia (BMI) yaitu Malang, Ponorogo, Blitar, Banyuwangi, Tulungagung, Madiun, Kediri, Bangkalan, Magetan, Jember, Trenggalek dan Ngawi. Data yang ada juga menunjukkan bahwa rata-rata setiap tahunnya buruh migran perempuan (BMP) mewakili $80 \%$ dan sebagian besar bekerja di sektor informal seperti di sektor rumah tangga, buruh pabrik, buruh bangunan, dan penjaga toko.

Didorong tuntutan meningkatkan ekonomi keluarga dan keluar dari keterpurukan kemiskinan, warga di perdesaan banyak yang mencalonkan diri sebagai buruh migran dengan mendaftarkan diri ke PJTKI setempat, dan kerapkali melalui jasa perantara (calo). Segala proses mereka lakukan termasuk tes kesehatan. Proses rekrutmen mensyaratkan calon buruh migran harus sehat dan menjadi ketentuan wajib bagi buruh migran yang akan ke luar negeri. Sejumlah syarat sehat yang harus dimiliki calon buruh migran dicantumkan di untuk sejumlah Negara tujuan, antara lain: 1) jantung sehat; 2) tidak dalam kedaan mengandung; 3) VDRL(-) (cek darah yang memastikan tidak adanya penyakit); 4) mata sehat/normal; 5) sehat jasmani dan rohani; 6) telinga tidak tuli; 7) sehat mental; 8) tidak bau mulut dan tidak memiliki penyakit pernafasan; 9) tidak pernah operasi; 10) tidak cacingan; 11) bebas penyakit kulit; dan 12) paru-paru sehat. 
Tabel 1.

Penempatan berdasar daerah asal (kota/kabupaten) (50 besar penempatan per tahun berdasar daerah) tahun 2011-2012

\begin{tabular}{|c|c|c|c|c|}
\hline No. & Daerah Asal & 2011 & 2012 & Jumlah \\
\hline 1 & Indramayu & 30.545 & 10.047 & 40.592 \\
\hline 2 & Lombok Timur & 28.429 & 7.671 & 36.100 \\
\hline 3 & Cilacap & 22.360 & 8.062 & 30.422 \\
\hline 4 & Lombok Tengah & 23.374 & 5.190 & 28.564 \\
\hline 5 & Cirebon & 19.844 & 6.049 & 25.893 \\
\hline 6 & Cianjur & 18.958 & 3.536 & 22.494 \\
\hline 7 & Brebes & 13.808 & 5.223 & 19.031 \\
\hline 8 & Karawang & 15.003 & 3.280 & 18.283 \\
\hline 9 & Kendal & 14.020 & 4.237 & 18.257 \\
\hline 10 & Malang & 13.414 & 4.635 & 18.049 \\
\hline 11 & Sukabumi & 13.578 & 2.837 & 16.415 \\
\hline 12 & Ponorogo & 11.561 & 4.495 & 16.056 \\
\hline 13 & Blitar & 11.369 & 4.300 & 15.669 \\
\hline 14 & Subang & 12.274 & 3.361 & 15.635 \\
\hline 15 & Serang & 13.204 & 1.058 & 14.262 \\
\hline 16 & Banyuwangi & 9.932 & 3.568 & 13.500 \\
\hline 17 & Lombok Barat & 10.069 & 2.693 & 12.762 \\
\hline 18 & Banyumas & 8.075 & 2.827 & 10.902 \\
\hline 19 & Tulungagung & 9.282 & 1.243 & 10.525 \\
\hline 20 & Majalengka & 8.067 & 2.109 & 10.176 \\
\hline 21 & Pati & 7.141 & 2.686 & 9.827 \\
\hline 22 & Bandung & 7.766 & 1.638 & 9.404 \\
\hline 23 & Madiun & 6.739 & 2.484 & 9.223 \\
\hline 24 & Tegal & 6.035 & 3.025 & 9.060 \\
\hline 25 & Jakarta Utara & 6.094 & 2745 & 8.839 \\
\hline 26 & Lampung Timur & 6.491 & 2059 & 8.550 \\
\hline 27 & Kediri & 6130 & 2350 & 8.480 \\
\hline 28 & Grobogan & 5.270 & 1.661 & 6.931 \\
\hline 29 & Bangkalan & 4.532 & 1.843 & 6.375 \\
\hline 30 & Sumbawa & 5.038 & 989 & 6.027 \\
\hline 31 & Purwakarta & 4.656 & 1.162 & 5.818 \\
\hline 32 & Magetan & 3.841 & 1.486 & 5.327 \\
\hline 33 & $\begin{array}{l}\text { Tangerang } \\
\text { (Kabupaten) }\end{array}$ & 4.481 & 781 & 5.262 \\
\hline 34 & Semarang & 3.799 & 1.457 & 5.256 \\
\hline 35 & Kebumen & 3.834 & 1.417 & 5.251 \\
\hline 36 & Jember & 3.942 & 1.146 & 5.088 \\
\hline 37 & Bekasi & 3.585 & 1.267 & 4.852 \\
\hline 38 & Trenggalek & 3.593 & 1.218 & 4.811 \\
\hline 39 & Kupang & 3.229 & 1.563 & 4.792 \\
\hline 40 & Lebak & 4.238 & 380 & 4.618 \\
\hline 41 & Medan & 3.188 & 1.385 & 4.573 \\
\hline 42 & Sragen & 3.476 & 1.072 & 4.548 \\
\hline 43 & Wonosobo & 3.376 & 1.172 & 4.548 \\
\hline 44 & Jakarta Timur & 3.230 & 1.207 & 4.437 \\
\hline 45 & Batang & 3.222 & 1.144 & 4.366 \\
\hline 46 & Demak & 3105 & 1.245 & 4.350 \\
\hline 47 & Ngawi & 2.962 & 1.111 & 4.073 \\
\hline 48 & Lampung Selatan & 3.089 & 875 & 3.964 \\
\hline 49 & Garut & 3.044 & 701 & 3.745 \\
\hline $\mathbf{5 0}$ & Banjarnegara & 2.650 & 908 & 3.558 \\
\hline 51 & Lain-Lain & 142.139 & 57.461 & 378.752 \\
\hline \multicolumn{2}{|c|}{ Total } & & & \\
\hline
\end{tabular}

Sumber: BNP2TKI - Badan Nasional Penempatan dan Perlindungan Tenaga Kerja Indonesia 
Ketatnya persyaratan yang ada mengharuskan setiap calon buruh migran melaksanakan tes kesehatan sebagai upaya deteksi dini. Proses ini dilakukan saat proses rekrutmen sebelum mereka berangkat ke negara tujuan, meliputi:1) datang check up harus mengisi biodata pribadi dan negara tujuan kemudian sekaligus pengambilan foto berukuran $4 \times 6$; 2) cekurin di kamar mandi untuk mengetahui calon BMP dalam keadaan hamil atau tidak; 3) pengambilan darah, untuk mengetahui mempunyai penyakit atau darah kotor seperti PMS atau terkena virus HIV; 4) rontgen untuk melihat kondisi paru-paru atau penyakit dalam lainnya; 5) cek mata dengan membaca dari jarak jauh untuk mengetahui calon BMI memiliki penyakit mata rabun atau tidak; dan 6) cek tubuh, calon BMP harus melepas seluruh bajunya kecuali celana dalam untuk mengetahui memiliki penyakit kulit atau tidak, calon BMP juga harus tidur terlentang di pegang payudaranya untuk mengetahui ada kanker payudara atau tidak, selain itu BMP juga dicek apakah pernah operasi atau tidak. Walaupun sudah melalui tahapan pemeriksaan yang ketat, tidak jarang calon BMP mengalami pemeriksaan ulang di negara tujuan. Terdapat sejumlah kasus dimana calon BMP dipulanhkan kembali ke Indonesia karena ditemukan penyakit menular, dan kejadian seperti ini tidak jarang menimbulkan pertanyaan tentang apakah proses yang deteksi dini yang dilakukan di Indonesia telah memenuhi standar internasional atau belum.

Ketatnya upaya deteksi dini sebelum keberangkatan, rupanya tidak sebanding dengan upaya serupa ketika BMI kembali ke tanah air. Baik pemerintah maupun PJTKI tidak mengeluarkan kebijakan untuk melakukan tes kesehatan sebelum sampai ke Indonesia. Padahal, proses kepulangan dan reintegrasi BMP ke daerah asal merupakan tahap penting dalam struktur perlindungan yang dipersyarakatkan oleh instrumen hukum baik internasional maupun nasional. Harapannya, BMP bisa kembali ke daerah asal dengan selamat. Pada saat kepulangan BMP ke Indonesia, fasilitas, pelayanan, perlindungan dan keadilan bagi buruh migran perempuan, sering mendapatkan diskriminasi dan penipuan dalam proses pemulangannya. Artinya, pelayanan dan perlindungan bagi mereka sangat minim.

Proses kepulangan/reintegrasi buruh migran perempuan merupakan tahap penting karena mereka akan dimasukkan ke Gedung Pendataan Kepulangan Khusus TKI (GPKTKI) Selapajang Tangerang. Di GPKTKI inilah akan diberi pelindungan dan pelayanan untuk meminimalisasi segala bentuk penipuan dan kekerasan yang diterima oleh buruh migran ketika kembali ke Indonesia. Bentuk dan pelayanan yang berada di GPKTKI (Butir ke tiga Peraturan Kepala BNP2TKI No. Per.01/KA/Su/1/2008), meliputi: 1) pemanduan keimigrasian; 2) pelayanan barang bawaan BMI; 3) pelayanan di lounge BMI; 4) penyediaan transportasi menuju gedung pendataan kepulangan BMI di Selapajang; 5) pelayanan pendataan; 6) pelayanan ticketing dan penjaluran; 7) penyediaan jasa transportasi kepulangan ke tempat tinggal BMI; 8) penanganan BMI bermasalah; 9) pelayanan kesehatan; 10) pelayanan keamanan; 11) pemanfaatan fasilitas gedung dan area bisnis; 12) pelayanan BMI transit; dan 13) pelayanan informasi dan pengaduan. Hal penting yang ternyata terlewatkan dari proses yang berlangsung di GPKTKI adalah tidak adanya kebijakan yang terkait dengan kebutuhan deteksi dini sebagaimana yang dialami dalam proses sebelu keberangkatan. Pelayanan kesehatan hanya diberikan kepada mereka yang mengeluh sakit.

Dalam kaitannya dengan HIV/AIDS, menurut laporan Perkembangan HIV/AIDS triwulan II tahun 2012 Kementerian Kesehatan RI (Ditjen PP\&PL Kemenkes 2012), jumlah kasus HIV tertinggi tercatat di DKI Jakarta (21.030 kasus), diikuti Jawa Timur (11.282 kasus), Papua (8.611 kasus), Jawa Barat (6.315 kasus) dan Sumatera Utara (5.629 kasus). Untuk kasus AIDS, terbanyak di DKI Jakarta (5.118 kasus), diikuti Papua (4.865 kasus), Jawa Timur (4.664 kasus), Jawa Barat (4.043 kasus), Bali (2.775 kasus), Jawa Tengah (1.948 kasus), Kalimantan Barat (1.358 kasus), Sulawesi Selatan (999 kasus), Riau (731 kasus) dan Yogyakarta (712 kasus). Selanjutnya, berdasarkan Laporan Perkembangan HIV/AIDS Kementerian Kesehatan RI bahwa Jawa Timur menduduki posisi kedua untuk kasus HIV dan posisi ketiga untuk kasus AIDS (Ditjen PP\&PL Kemenkes 2013). Penyebaran HIV/AIDS di Jawa Timur tentunya cukup memprihatinkan, apalagi ketika dikaitkan salah satunya disebabkan dampak dari BMI di negara tujuan.

Sumber lain, Coordination of Action Research on AIDS and Mobility Asia (CARAM Asia) merilis bahwa dari sekitar 6 juta buruh migran, sebanyak 80\% adalah Buruh Migran Perempuan (BMP). 
Selain buruh migran laki-laki, BMP tertular HIV/AIDS di negara tempat mereka bekerja. Dinas Tenaga kerja Propinsi Jawa Timur mengeluarkan data terkait peredaran virus HIV/AIDS. Dimana Disnakertrans Jatim mengeluarkan data sebanyak 4.000 BMI Jatim diindikasikan terinfeksi virus HIV/AIDS. Demikian juga seperti di VCT Rumah Sakit Margono Soekarjo, ditemukan 32 orang mantan BMI dan keluarganya sudah terjangkit virus HIV/AIDS. Hal ini disebabkan BMI rentan terkena virus HIV/AIDS karena tingginya mobilisasi mereka, terutama ketika berada di wilayah endemis HIV/AIDS.

Sementara itu, data yang diperoleh melalui BNP2TKI setidaknya menunjukkan bahwa hingga tahun 2011, Peduli Buruh Migran, setidaknya menangani 50 Kasus buruh migran tidak berdokumen dari Malaysia yang terinfeksi HIV/AIDS. Pada tahun 2010, Peduli Buruh Migran di Malang menemukan sebanyak 58 buruh migran dipulangkan karena menderita HIV/AIDS. Angka itu naik menjadi 66 orang pada 2011. Dari data ini, menunjukkan bahwa ketidakmampuan pemerintah dalam melindungi hak-hak buruh migran mengakibatkan Buruh Migran Indonesia semakin rentan terhadap penularan HIV/AIDS. Kondisi ini diperparah dengan posedur penanganan kasus HIV/AIDS di kalangan pekerja migran yang tidak jelas, dan oleh karena itu masalah kesehatan pada BMI sebelum kembali ke desa asal menjadi masalah yang penting untuk diperhatikan. Data reintegrasi BMI yang bermasalah dapat dilihat pada tabel 2 .

Tabel 2.

Kepulangan BMI di Bandara Juanda Surabaya (2006 - 31 Mei 2012)

\begin{tabular}{cccc}
\hline Tahun & Kepulangan & BMI Bermasalah & Prosentase (\%) \\
$\mathbf{2 0 0 6}$ & 53,197 & 4,128 & 7.8 \\
$\mathbf{2 0 0 7}$ & 64,011 & 3,558 & 5.6 \\
$\mathbf{2 0 0 8}$ & 86,919 & 4,952 & 5.7 \\
$\mathbf{2 0 0 9}$ & 96,085 & 8,249 & 8.6 \\
$\mathbf{2 0 1 0}$ & 86,232 & 6,273 & 7.3 \\
$\mathbf{2 0 1 1}$ & 85,540 & 5,167 & 6.0 \\
$\mathbf{2 0 1 2}$ (sampai 31 Mei) & 33,258 & 1,852 & 5.6 \\
\hline
\end{tabular}

Sumber: BNP2TKI - Badan Nasional Penempatan dan Perlindungan Tenaga Kerja Indonesia

Menghadapi data-data ini, diperlukan sikap jelas untuk membangun suprastruktur dan infrastruktur yang memberikan perlidungan bagi BMI khususnya dalam hal kesehatan terutama HIV/AIDS. Untuk itu membangun model kebijakan perlindungan buruh migran Indonesia melalui deteksi dini akan menjadi basis operasional pelayanan sebagai semangat perlindungan terhadap BMI sebelum berintegrasi kembali dengan keluarga.

\section{Hasil Penelitian dan Pembahasan}

Secara umum, hasil dan pembahasana penelitian ini menyinggung tiga hal penting. Pertama hal yang berkaitan dengan prosedur reintegrasi yang dialami BMI ketika mereka pulang dibandingkan dengan prosedur sebelu keberangkatan. Kedua, isu-isu kesehatan dan hak buruh migran yang bersinggungan dengan peran GPKTKI dan dinas-dinas terkait. Ketiga, sorotan atas dampak dari masih lemahnya kebijakan pemerintah.

Dari penelusuran informasi di BNP2TKI dan Disnaker maupun wawancara dengan berbagai informan kunci, tidak ditemukan data yang menjelaskan adanya praktik pemeriksaan kesehatan BMI di bandara kedatangan maupun di tempat-tempat kedatangan yang lain. Bahkan PPTKIS yang memberangkatkan para Buruh Migran pun tidak melakukan pemeriksaan itu. Hal ini kontras dengan situasi sebelum berangkat ke luar negeri, BMI diwajibkan melakukan pemeriksaan kesehatan secara ketat, terutama untuk mengidentifikasi jenis-jenis penyakit. Pemeriksaan kesehatan secara ketat merupakan syarat 
sehat sebelum berangkat dan menjadi ketentuan wajib bagi buruh migran yang akan ke luar negeri; sejumlah syarat sehat yang harus dimiliki calon buruh migran dicantumkan dibeberapa negara tujuan.

Bagi mereka yang terbukti terpapar penyakit, atau sedang hamil, umumnya keberangkatannya ke negara tujuan dibatalkan. Di dalam beberapa kasus, meskipun persyaratan pemeriksaan kesehatan itu diberlakukan secara ketat, akan tetapi di dalam prakteknya, banyak buruh migran tetap bisa lolos dan berangkat ke luar negeri karena waktu antara pemeriksaan kesehatan dengan keberangkatan buruh migran yang bersangkutan bisa berselang antara tiga hingga enam bulan. Diantara waktu jeda ini, ada banyak kemungkinan tindakan PPTKIS maupun buruh migran sendiri yang dapat menjadi pemicu timbulnya penyakit.

Pemeriksaan terhadap BMI pada fase kedatangan menjadi kebutuhan yang penting dan mendesak, karena banyaknya kasus-kasus kesehatan yang diderita buruh migran bisa bersumber pada penyakit akibat kerja, akibat kecelakaan kerja maupun akibat pergaulan di negara tujuan. Tidak dilakukannya pemeriksaan kesehatan pada saat kedatangan ditengarai disebabkan oleh beberapa hal. Pertama, belum adanya Standard Operating Prosedure (SOP) pemeriksaan kesehatan Buruh Migran yang dibuat dan dimiliki oleh Kementerian Tenaga Kerja maupun BNP2TKI. Kedua, waktu kedatangan buruh migran di bandara umumnya malam atau dini hari, yakni waktu di mana klinik kesehatan yang ada di bandara sudah tutup. Ketiga, buruh migran sendiri yang tidak melakukan pemeriksaan kesehatannya. Keempat, para petugas kesehatan yang ada hanya melihat sepintas kondisi fisik para buruh migran. Jika tampaknya keadaan fisik buruh migran itu normal, maka mereka dianggap sehat-sehat saja. Kelima, persepsi petugas maupun buruh migran mengenai sehat-sakit mempengaruhi apakah pemeriksaan kesehatan dilakukan atau tidak. Jenis-jenis penyakit tertentu, seperti flu/pilek misalnya, baik bagi buruh migran maupun petugas kesehatan tidak dipersepsikan sebagai penyakit yang serius atau beresiko, sehingga untuk jenis penyakit seperti ini tidak dilakukan pemeriksaan kesehatan. Tidak memadainya pelayanan pemeriksaan medis terhadap BMI berimbas pada ketiadaan pelayananpemeriksaan kesehatan non-medis untuk mengetahui penyakit-penyakit yang bersifat psikologis. Sebabnya adalah, ada banyak kasus di mana tekanan kerja (akibat jam kerja yang sangat panjang, beban kerja terlalu berat, kerja tidak sesuai keahlian, dan lain-lain) atau karena tindakan majikan (intimidatif, intoleran, kekerasan, perkosaan dan lain-lain) dalam suasana terisolasi dan teralienasi dapat menimbulkan trauma bagi buruh migran perempuan.

Lemahnya pengaturan mengenai keharusan dilakukannya pemeriksaan kesehatan saat kedatangan buruh migran bukan saja menimbulkan situasi diskriminatif bagi buruh migran, akan tetapi beresiko lebih besar, yakni tiadanya kontrol terhadap penyebaran berbagai penyakit menular, termasuk penyakit menular seksual dan HIV/AIDS, ke dalam kehidupan masyarakat luas di Indonesia. Tanpa ada SOP yang mengatur dan menetapkan mekanisme dan prosedur pemeriksaan kesehatan dan tanpa ada tindakan pemeriksaan kesehatan buruh migran di saat kedatangan yang sama ketatnya dengan pemeriksaan kesehatan pada waktu mereka berangkat, maka sangat masuk akal jika muncul anggapan bahwa buruh migran diperlukan tidak adil dan diskriminatif oleh negaranya sendiri.

Pemeriksaan kesehatan dan deteksi dini sangat dianjurkan untuk dilaksanakan karena di satu sisi hal itu menjadi hak buruh migran, di sisi yang lain menjadi kewajiban negara untuk memenuhinya. Hal ini tercermin di dalam UU No, 39/1999 mengenai Hak Asasi Manusia yang menyatakan bahwa kewajiban untuk menghormati, melindungi, memajukan dan memenuhi hak asasi manusia ada pada negara (pasal 71) dan kewajiban-kewajiban itu harus diwujudkan di dalam kebijakan negara yang dapat diimplementasikan secara efektif (pasal 72). Tiadanya kebijakan negara, dalam hal ini Kementerian Tenaga Kerja dan BNP2TKI yang mengatur kewajiban bagi para pihak yang berkompeten - termasuk PPTKIS — untuk melakukan pemeriksaan kesehatan buruh migran di saat kedatangannya, yang sama ketatnya dengan pemeriksaan kesehatan di saat menjelang keberangkatan mereka, merupakan pelanggaran hak asasi buruh migran umumnya dan buruh migran perempuan khususnya. Pelanggaran hak asasi dalam bentuk diskriminasi, maupun pelanggarakan terhadap UUD'45 pasal 28 J dan UU No.39/1999 terutama pasal 71 dan 72. 
Fakta-fakta ini menunjukkan bahwa pemerintah belum memiliki SOP yang jelas mengenai pemeriksaan kesehatan saat kedatangan BMI; standar klinik dan fungsiya perlu diperjelas termasuk SOP pada saat kedatangan buruh, jenis penyakit apa saja yang diperiksa, di mana tempat pemeriksaan dilakukan, termasuk berapa biayanya, dan siapa yang menanggung pembiayaannya.

Hampir 50\% buruh migran adalah perempuan dan dari tahun ke tahun jumlahnya cenderung meningkat. Dari 191 juta migran internasional yang terdata pada tahun 2005, 94,5 juta di antaranya adalah perempuan dengan 12,7 juta di antaranya mengalami forced migration. Oleh karena itu muncullah konsep gendered migration yang mencoba untuk menganalisa mengapa hal tersebut bisa terjadi dan apa yang terjadi di dalamnya. Dari tipe-tipe yang disebutkan di atas, buruh perempuan khususnya di Asia sebagai pemasok migran terbesar, menurut Yamanaka dan Piper (2005) melakukan pekerjaan sebagai pekerja rumah tangga, entertainers dan/atau pekerja seks, pekerja ilegal, menjadi istri, skilled workers dan pekerja yang membagikan warisan budaya negaranya ke negara tujuan.

Fenomena sebagaimana dikemukakan Yamanaka dan Piper di atas, juga termasuk yang terlihat dalam hasil penelitian ini. Namun demikian, pengetahuan tentang kesehatan bagi BMI nampaknya belum menjadi prioritas; para BMI sangat kurang pemahamannya mengenai bagaimana dampak dari pekerjaan selama menjadi buruh migran serta apa yang harus mereka lakukan ketika BMI divonis terkena penyakit tertentu. Situasi ini diperparah oleh keterbatasan kemampuan mereka terhadap akses dan informasi dalam pelayanan kesehatan. Di lapangan para BMI umumnya hanya mengalami pelayanan kesehatan pemeriksaan kesehatan yang terlihat pada permukaan atau pada tubuh BMI, penyakit seperti batuk pilek tidak termasuk dalam pemerikasaan. Anggapan kebanyakan orang Indonesia, penyakit batuk dan pilek hanya "penyakit warung" (penyakit yang bisa disembuhkan oleh obat yang dijual warung). Terdapat juga sejumlah kasus dimana pelayanan kesehatan ini disalah gunakan oleh oknum yang tidak bertanggung jawab untuk memperoleh keuntungan sepihak dengan modus operandinya penyakit yang dilarang di Indonesia sehingga para BMI tidak boleh masuk ke Indonesia. BMI bisa melewati pemeriksaan kesehatan tersebut dengan cara membayar sejumlah uang, agar pemeriksaan menjadi lancar.

Deteksi dini seperti pemeriksaan darah tidak mungkin dilaksanakan dalam waktu singkat bahkan ada lembaga yang mengusulkan untuk bekerja sama dengan negara di mana dia bekerja. Pemeriksaan dilakukan di sana, sehingga efisiensi dapat terjadi. BMI dengan cepat dapat pulang kerumah masingmasing, namun hal ini tidak mungkin dilakukan sebab negara tempat mereka bekerja tidak mendapat keuntungan apapun dari BMI yang berkerja di negaranya. Banyak sekali ide teknis yang dilontarkan seperti diatas, bahkan ada yang mengusulkan screening kesehatan dilakukan oleh agen yang memberangkatkan mereka ke negara tempat tujuan mereka bekerja. Model ini yang paling memungkinkan, karena proses pengecekan bisa dilakukan dengan tidak berkejaran waktu bahkan pendekatan bisa dilakukan dengan pendekatan kekeluargaan.

Ada tiga klasifikasi penyakit yang paling banyak diderita oleh BMI yaitu penyakit akibat kerja, penyakit kecelakaan kerja dan penyakit akibat seks bebas. HIV/AIDS adalah penyakit yang banyak diderita oleh BMI, karena banyaknya berhubungan intim dengan pasangan yang berbeda. Misalkan mereka yang bekerja di Malaysia, pada saat libur biasanya mereka akan berkumpul di Victoria Park, pekerja satu dan yang lainnya akan berkenalan, mengobrol dan tidak jarang pertemuan itu berakhir di kamar hotel. Bahkan ini dilakukan berulang kali dengan pasangan yang berbeda. Sedangkan kasus lainnya BMI yang bekerja di Arab Saudi, dipaksa untuk melayani nafsu birahi majikanya. Akhirnya kategori hanya dibagi menjadi dua bagian, yaitu penyakit akibat kerja dan penyakit kecelakaan kerja.

Tes kesehatan wajib dilakukan untuk mencegah penyebaran HIV, akan tetapi tes tersebut menurut Serikat Pekerja justru akan menguatkan stigmatisasi, diskriminasi dan pengucilan terhadap individu atau migran yang terinfeksi Virus HIV. Untuk melawan hal tersebut, penting untuk menegakkan prinsip hak asasi manusia dalam pembuatan hukum dan kebijakan yang mencakup kesehatan buruh migran. Selain itu, harus disadari bahwa buruh migran dengan HIV positif dapat tetap produktif untuk bertahun-tahun dan berkontribusi pada struktur sosial, ekonomi dan kebudayaan, baik negara tujuan 
dan negara asal. Sehingga pekerja migran yang positif HIV tetap memiliki peran penting dalam meningkatkan kesadaran publik mengenai HIV dan mengurangi stigmatisasi yang mengarah pada pembentukan hukum dan kebijakan yang diskrirninatif.

Kebijakan tes kesehatan wajib dinilai telah gagal memperhitungkan berbagai faktor yang dapat mengikis kesehatan dan kesejahteraan buruh migran begitu mereka tinggal di dalam batasan negara. Keputusan yang diambil saat ini berdasarkan atas dasar ketakutan, termasuk tentang kesejahteraan migran. Lebih lanjut, temuan penelitian yang menantang adaptasi kebijakan tes kesehatan wajib telah diabaikan untuk keuntungan politik.

Pengabaian status HIV seseorang dapat mempunyai konsekuensi serius, seperti pengobatan terlambat yang mengakibatkan memburuknya kesehatan dan munculnya biaya lain, dan potensi menginfeksi orang lain. Penelitian menunjukkan ada dua alasan umum mengapa orang tidak mengikuti konseling HIV: pertama terbatasnya layanan tes HIV; kedua stigma dan diskriminasi sosial yang diasosiasikan dengan infeksi HIV. Kedua faktor ini memainkan peran penting dalam kurangnya kesadaran penduduk di negara berkembang dan mengakibatkan penyebaran penyakit ini terus meningkat.

Oleh karena itu, dasar peningkatan tes dan konseling HIV harus mencakup pada peningkatan perlindungan TKI dari stigma dan diskriminasi dan memperoleh jaminan akses atas layanan pencegahan, pengobatan dan perawatan yang terintegrasi. Kondisi-kondisi di mana orang melakukan tes HIV harus berakar pada pendekatan hak asasi manusia yang melindungi hak-hak dasar mereka dan menghormati prinsip-prinsip etis kerahasiaan, konseling dan pernyataan persetujuan.

Lemahnya jaminan pemenuhan hak-hak normatif buruh migran juga masih harus mendapat perhatian. Hak-hak normatif ini adalah, pertama, hak mendapatkan upah layak, hak mendapatkan upah lembur, hak mendapatkan hari libur, hak mendapatkan jaminan kesehatan keselamatan kerja, hak beribadah, hak kebebasan berserikat, hak kebebasan berekspresi, hak berkomunikasi, dan hak memegang paspor sendiri; kedua, hak atas kesehatan seksual dan reproduksi buruh migran perempuan (tidak ada cuti haid, dilarang bekerja karena hamil, termasuk tidak diberangkatkan atau dideportasi karena hamil) dan hak untuk menikah; ketiga, hak bekerja bagi buruh migran yang terinfeksi HIV/AIDS (adanya mandatory test bagi calon pekerja migran, dan deportasi ketika terindikasi terinfeksi HIV/AIDS); dan keempat, hak untuk memperoleh bantuan hukum bagi buruh migran yang terkait masalah hukum di negara tempat bekerja.

Contoh kasus yang banyak dialami oleh buruh migran Indonesia adalah mereka diwajibkan mengikuti pemeriksaan kehamilan sebelum keberangkatan dan dideportasi apabila hasilnya positif bahkan mereka dipaksa melakukan aborsi. Oleh karena terbentur tidak adanya kesempatan/sarana untuk mendapatkan pelayanan kesehatan reproduksi dan aborsi yang aman dan memadai banyak kasus seorang calon ibu berisiko lebih tinggi, bahkan jika mereka mengalami serangan seksual; BMI juga tidak diberi cuti hamil dan tunjangan bersalin atau kalau pun diberi biaya tersebut tidak mencukupi, dan tidak mendapatkan perawatan dokter kandungan karena biayanya tidak terjangkau, hal ini mengakibatkan risiko kesehatan calon ibu mejadi serius atau parah. Buruh migran perempuan juga kemungkinan akan menghadapi pemutusan hubungan kerja ketika mereka hamil; yang menyebabkan status keimigrasian mereka menjadi tidak jelas dan pada akhirnya mereka akan deportasi. Untuk itulah maka mekanisme jaminan pemenuhan hak-hak Buruh Migran Indonesia ASEAN yang akan disusun harus ikut berkontribusi dalam proses standarisasi perlindungan hak asasi buruh migran pada tingkat regional.

Standarisasi perlindungan dimaksud meliputi aspek-aspek berikut. Pertama, standarisasi perburuhan atas hak-hak normatif bagi setiap buruh migran terkait upah layak, upah lembur, hari libur, jaminan kesehatan dan keselamatan kerja, kebebasan berserikat, kebebasan berekspresi, berkomunikasi, dan beribadah. Pelarangan diskriminasi upah berdasarkan, ras, etnis, gender, agama, dan bahasa di kawasan ASEAN. Kedua, standarisasi majikan yang diijinkan mempekerjakan PRT; hal itu untuk memastikan bahwa orang yang akan mempekerjakan PRT tidak mempunyai track record melakukan kekerasan terhadap pekerjanya, mampu membayar upah sesuai standar yang ditentukan, dan bersedia 
memenuhi hak-hak bekerja standar yang telah ditentukan ASEAN. Ketiga, standarisasi kurikulum pendidikan bagi buruh migran yang berbasiskan pada HAM dan keadilan jender; menjamin terpenuhinya hak atas informasi dan pendidikan atau pengembangan diri buruh migrant. Pemerintah perlu mengambil alih peran penyelenggara pendidikan keberangkatan dan bekerja sama dengan serikat pekerja atau NGO dalam melakukannya. Menghapus persyaratan wajib menetap di penampungan selama masa pendidikan.

Keempat, standarisasi layanan kesehatan dan pemenuhan hak-hak reproduksi buruh migran perempuan pada keseluruhan proses migrasi, mulai dari proses Deteksi dinisebelum keberangkatan dan di Negara tujuan, hingga layanan kesehatan umum di tempat kerja dan di terminal kepulangan, serta tempat-tempat penahanan dan shelter/pusat rehabilitasi, baik di negara asal maupun di negara tujuan; deteksi dini yang dilakukan harus bebas dari praktek pelecehan seksual, meniadakan mandatory test HIV/AIDS bagi calon pekerja migran, memberi jaminan hak-hak bekerja bagi pekerja migran dengan HIV/AIDS, jaminan kerja bagi buruh migran yang hamil, dan tidak ada deportasi bagi yang menderita HIV Aids atau hamil; serta perlu juga dibuka akses layanan VCT, konseling dan tes kehamilan bagi buruh migran migran perempuan di negara tujuan. Kelima, standarisasi biaya pemberangkatan bekerja di luar negeri. Pemerintah di negara tujuan perlu menetapkan aturan yang melarang majikan memotong seratus persen gaji pekerja migran setiap bulannya.

Hasil diskusi yang diperoleh di lapangan saat forum diadakan menjelaskan bahwa sekalipun diberlakukan medical screening, tidak berarti akan ada langkah lebih lanjut dari pihak PPTKIS maupun Pemerintahan yang menangani. Hal ini dikarenakan banyak para TKI yang pulang ke Indonesia, terutama saat ada kepulangan massal (dalam jumlah besar) dan kurangnya tenaga dari pihak pemeriksa merupakan salah satu kendala dari berlakunya deteksi dini. Biasanya apabila TKI tersebut pulang dengan keadaan sehat atau secara fisik tampak sehat, maka pihak tenaga pemeriksa beranggapan bahwa keadaan BMP keseahatnnya baik dan tidak memerlukan perlakuan lebih lanjut seperti Deteksi dini. Jumlah tenaga periksaan sedikit dan tidak sebading dengan BMP yang kembali atau keterbatasan kemampuan serta pengetahuan tenaga pemeriksa tersebut menyebabkan para TKI tidak mengetahui apakah mereka dalam keadaan sehat atau sakit setelah beberapa lama bekerja di luar negeri, karena pihak pemerintah sendiri ada yang tidak mewajibkan deteksi dini itu sendiri.

Setiap pemberangkatan ke berbagai negara di bagian yang berbeda, maka berbeda pula tempat berangkat maupun tempat pulangnya, seperti para TKI yang bekerja di area Asia Pasifik misalnya, mereka lebih memilih bandara Juanda Surabaya menjadi tempat kepulangan mereka, selain itu biaya deteksi dini di Bandara Juanda Surabaya lebih murah, tetapi yang membuat para TKI memilih Bandara Juanda Surabaya karena di bandara ini tidak memawajibkan deteksi dini tersebut, padahal area Asia Pasifik merupakan area yang terkenal dengan adanya penularan penyakit seksual. Hambatan diberlakukannya deteksi dini selain kurangnya tenaga pemeriksa kesehatan, termasuk kurangnya peralatan dan obat-obatan dalam pos-pos maupun klinik di bandara tujuan. Selain itu yang paling ditakutkan oleh pihak LSM maupun pemberdayaan masyarakat, adalah munculnya pungutan liar di setiap klinik maupun di pos kesehatan.

Menghadapi sejumlah fakta diatas maka optimalisasi peran GPKTKI masih sangat perlu ditingkatkan. Koordinasi dengan dinas-dinas terkait juga masih perlu diperkuat. Kurang optimalnya kerangka kerja yang mengabaikan proses deteksi dini, terutama yang berkaitan dengan kasus HIV/AIDS tentu akan memberi dampak luas kepada keluarga dan masyarakat dimana para buruh migrant berasal.

Mayoritas buruh migran yang diwawancarai menjelaskan bahwa mereka bekerja keluar negeri, tidak lain untuk memperbaiki perekonomian. Buruh migran perempuan ini jelas mengalami dilema dan beban ganda, yaitu keluar dari ranah domestik untuk bekerja kembali di ranah domestik yaitu sebagai Pekerja Rumah Tangga/PR guna menghidupi biaya hidup keluarga.Pelabelan kerja domestik tersebut yang mengakibatkan opresi pola integrasi kapitalisme dan patriarkhal. Bahwa, upah perempuan tidak layak besar, karena pekerjaan yang dikerjakan merupakan kerja domestik, bukan publik. Selain itu, semakin murah upah yang dibayarkan bagi buruh migran perempuan, semakin banyaklah permintaan dari negara-negara tujuan. 
Inti dari diskusi FGD menghasilkan bahwa deteksi dini dianggap perlu, karena seharusnya jika pihak Indonesia mengirimkan BMI dalam keadaan sehat (disahkan melalui cek kesehatan ketat yang dilakukan sebelum keberangkatan BMI) maka diharapkan para BMI pulang ke Indonesia juga dalam keadaan sehat. Sehat yang dimaksudkan disini adalah sehat secara keseluruhan, bukan hanya penampakan secara kasat mata dari fisik BMI tersebut, karena pada kenyataannya banyak BMI yang sebenarnya menderita sakit yang cukup parah namun tidak kasat mata, termasuk HIV/AIDS dan penyakit kelamin menular lainnya. PPTKIS sebagai pihak yang memberangkatkan dan memulangkan BMP seharusnya bertanggung jawab penuh atas keselamatan, keamanan termasuk kesehatan BMP. Jadi kewajiban deteksi dini harus diproses oleh pihak PPTKIS tersebut. Biaya proses deteksi dini ditanggung dan dibayar oleh BMI tetapi kewajiban atas deteksi dini harus dilembagakan atau diatur sebagai salah satu proses dari pemberangkatan hingga pemulangan para BMP.

Secara umum, permasalahan-permasalahan kesehatan yang dialami buruh migran Indonesia (BMI) saat bekerja di luar negeri dan setiba di Indonesia dapat dideskripsikan sebagai berikut. Saat berangkat sudah dilakukan pengecekan kesehatan. Mereka yang berangkat pasti sehat, karena pemeriksaan kesehatan sangat ketat. BMI tidak boleh berangkat atau pemberangkatannya ditunda jika meraka tidak lolos test kesehatan baik secara fisik maupun psikologis. Permasalahan kesehatan, biasanya muncul saat mereka sudah bekerja di luar negeri. Pada umumnya permasalahan kesehatan yang dialami, berupa gangguan kesehatan fisik, kesehatan seksual dan reproduksi maupun gangguan kesehatan mental. Gangguan kesehatan mental tercermin dari tingginya mereka yang menjadi lesbian. Gangguan kesehatan seksual dan reproduksi tercermin dari penyakit menular seksual (PMS) dan HIV/AIDS (Hongkong), dan aborsi (Taiwan). Terdapat perbedaan perilaku dan permasalahan kesehatan antara BMP yang bekerja di Taiwan dan Hongkong. Permasalahan di Taiwan kebanyakan adalah Aborsi; sedangkan di Hongkong adalah PMS dan HIV. Kebijakan deteksi dini dianggap efektif dijalankan saat menjelang keberangkatan. Sedangkan deteksi dini saat kepulangan dianggap tidak terlaksana dengan efektif. karena berbagai faktor. Antara lain: karena kebijakan tersebut tidak ditegakkan secara sungguh-sungguh; BMP merasa tidak punya masalah kesehatan; BMP tidak suka berhubungan lagi dengan PPTKIS saat kepulangan, sehingga kepulangan mereka sering di luar pemantauan peruhasaan pengirim.

Keharusan melakukan psycho-test secara lengkap untuk calon tenaga kerja yang mau berangkat maupun saat kepulangan kembali ke tanah air. Psycho-test harus dilakukan untuk menegecek aspek kejiwaan para BMI. Seringkali terjadi ada kecenderungan bunuh diri, lesbian, melakukan seks bebas, prostitusi dan lain-lain, namun, dalam pelaksanaan tidak bisa dijalankan secara konsisten karena berbagai faktor. Antara lain, karena faktor keterbatasan profesi psikolog yang memenuhi syarat standar kompetensi yang sesuai aturan. Ada juga BMI yang berangkat pada umumnya sudah bermasalah secara psiko-sosial. Mereka pergi, bekerja ke luar negeri karena terpaksa, karena tekanan berbagai faktor. Faktor-faktor tersebut, antara lain: tekanan kemiskinan, tekanan/keretakan rumah tangga, korban kekerasan, terbelit hutang.

Menurut pengusaha, ibaratnya bila ada 10 BMP, maka ada 100 permasalahan. Permasalahan keluarga, menjadi faktor dominan sekaligus pemicu mereka bekerja sebagai tenaga kerja di luar negeri. Pengusaha merasakan bahwa riwayat perilaku dan penyakit yang terkait dengan seksualitas dan reproduksi perlu diperiksa secara mendalam sebelum berangkat dan setelah pulang. Pemeriksaan kesehatan reproduksi dan seksual dianggap sangat penting pada saat awal maupun saat kepulangan. Data-data yang ada menunjukkan bahwa BMP banyak yang yang bermasalah dengan kesehatan reproduksi dan kesehatan seksual. Tercermin pada tingginya kasus-kasus: aborsi, PMS \& HIV. Mereka yang korban pemerkosaan cenderung mengarah menjadi lesbian atau terjebak pada seks bebas dan prostitusi. Terdapat beberapa permasalahan terkait standar pemeriksaan dan waktu pemeriksaan. Saat berangkat dinyatakan sehat, tetapi begitu mereka sampai di negara tujuan dinyatakan tidak sehat. Hal ini kemungkinan disebabkan karena model dan standarisasi pemeriksaan tidak sesuai dengan standar kesehatan yang seharusnya. Selain itu juga disebabkan faktor lain, misalnya, setelah mereka diperiksa, ternyata pada waktu 1 bulan sebelum keberangkatan BMP melakukan hubungan seksual dan hamil, atau mereka terserang gangguan kesehatan setelah dilakukan tes kesehatan. 
Di setiap negara tujuan mempunyai aturan yang berbeda-beda tentang pemeriksaan kesehatan, ada yang berlaku 1 tahun sekali, ada yang berlaku 6 bulan sekali. Pihak PPTKIS selalu merasa menjadi kambing hitam atas nasib BMI. Apa yang dikatakan Pemerintah bahwa BMI sebagai pahlawan devisa hanya slogan semata. Pemerintah tidak menghargai BMI dan tidak memberi lapangan kerja. Kerancuan penanganan BMI dan BMP semakin tinggi, ketika ada dualisme kewenangan antara Kementerian Tenaga Kerja \& Transmigrasi dan BNP2TKI, yang selalu tidak akur. Di Jawa Timur, bahkan ada tiga lembaga yang menangani, yakni ada kewenangan dari Propinsi Jawa Timur, Pengaturan yang rancu dan tidak kompak ini membuat PPTKIS menjadi serba salah. Pengusaha mengeluhkan mata rantai birokrasi pengurusan yang menjadi semakin panjang dan sulit. Perspektif pemerintah terhadap BMI dan BMP dianggap tidak jelas dan kurang transparan. Di satu sisi, mereka dianggap pahlawan devisa, namun perlakuan terhadap BMI/BMP masih diwarnai diskriminatif. Mereka diperlakukan secara berbeda, dari pasport, maupun terminal kedatangan, yang dibedakan dengan penumpang umum.

\section{Simpulan}

Setiap Buruh Migran yang berangkat ke luar negeri secara legal diwajibkan untuk memeriksakan kesehatannya terlebih dahulu. Rekam jejak kesehatannya menjadi prasyarat untuk kelengkapan dokumen, selain paspor dan kelengkapan lainnya. Di negara tujuan, pemeriksaan juga dilakukan terhadap Buruh Migran yang baru datang. Dengan kata lain, kondisi kesehatan para Buruh Migran yang hendak berangkat maupun sesudah di negara tujuan, dipantau dengan ketat. Hal ini sekurangkurangnya memiliki dua alasan. Pertama, negara tujuan hendak memantau dengan ketat penyebaran berbagai penyakit menular akibat arus migrasi lintas negara yang dalam hal ini dilakukan Buruh Migran. Kedua, para majikan atau calon majikan tidak mau jika Buruh Migran yang bekerja kepadanya adalah Buruh Migran yang tidak sehat, lebih-lebih jika Buruh Migran yang bersangkutan menderita penyakit menular.

Sebaliknya pemerintah belum memberlakukan kewajiban bagi buruh migran untuk melakukan pemeriksaan kesehatan sebagai deteksi dini ketika pulang ke Indonesia sampai ke daerah asal. Belum dilakukannya optimalisasi deteksi dini Kementerian Tenaga Kerja dan BNP2TKI, di antaranya diakibatkan hal-hal berikut. Pertama, pembiayaan untuk suatu proses deteksi dini yang baik tentu membutuhkan peralatan kesehatan yang baik dan untuk itu pembiayaanya dipastikan tinggi. Kedua, political will dari pemeritah masih terlihat lemah dan ini terlihat dari masih lemahnya komitmen koordinasi pemerintah terhadap perlindungan hak-hak standar buruh migram. Ketiga, keengganan atau bahkan penolakan BMI untuk diperiksa sesudah tiba di tanah air. Dalam konteks ini, Pemerintah dihadapkan pada keharusan adanya "informed consent" dari BMI yang hendak diperiksa. Atas nama hak asasi manusia, dibutuhkan payung hukum yang jelas sampai pada tingkat implementasi berkaitan dengan urusan pemeriksaan sebagai langkah awal deteksi dini, terutama berkaitan dengan deteksi dini HIV/AIDS sebelum para BMI ini berintegrasi kembali ke dareah asalnya.

Memperhatikan simpulan-simpulan penelitian ini, sudah waktunya pemerintah membangun sistem pelayanan satu atap (one roof system) yang jauh lebih baik dengan melibatkan tidak saja departemen atau dinas-dinas terkait, tetapi juga mengikutsertakan pemangku kepentingan lainnya di luar sektor pemerintahan. Sebagaimana disebutkan di awal tulisan ini, kecenderungan meningkatnya jumlah BMI tak terhindarkan di masa-masa mendatang. Untuk itu tren peningkatan tersebut perlu diimbangi oleh mutu pelayanan yang lebih baik sehingga label pahlawan devisa tidak hanya sekedar slogan tetapi bermakna dalam artian sesungguhnya. 


\section{Daftar Pustaka}

Azmy AS (2011) Negara dan buruh migran perempuan, kebijakan perlindungan buruh migran perempuan Indonesia masa pemerintahan Susilo Bambang Yudhoyono 2004-2010. Tesis, Fakultas Imu Sosial dan Ilmu Politik, Departemen Ilmu Politik, Program Pasca Sarjana Ilmu Politik, Universitas Indonesia.

BNP2TKI (2012) Penempatan dan perlindungan tenaga kerja Indonesia tahun 2012. Jakarta: Pusat Penelitian Pengembangan dan Informasi.

BNP2TKI (2013) Penempatan dan perlindungan tenaga kerja Indonesia 2013. Jakarta: Pusat Penelitian Pengembangan dan Informasi.

Ditjen PP \& PL Kementerian Kesehatan RI (2012) Laporan situasi perkembangan HIV/AIDS di Indonesia tahun 2012. Jakarta: Ditjen PP\&PL Kementerian Kesehatan RI.

Ditjen PP\&PL Kementerian Kesehatan RI (2013) Laporan situasi perkembangan HIV/AIDS di Indonesia tahun 2013. Jakarta: Ditjen PP\&PL Kementerian Kesehatan RI.

Farbenblum B, Taylor-Nicholson E, Paoletti S (2013) Akses buruh migran terhadap keadilan di negara asal: Studi Kasus Indonesia. New York: Open Society Foundations.

Hugo G (2001) Indonesia, internal \& international population mobility: Implicatios for the Spread of HIV/AIDS. Indonesia: ILO, UNDP, WHO, AusAID.

Koesrianti (2010) Kewajiban negara pengirim dan negara penerima atas perlindungan Pekerja migran. Jurnal Diplomasi Vol 2(1):21-40.

LPKP (2010) Kampanye imigrasi aman, Kerjasama LPKP dengan IOM, Malang: LPKP.

McCulloch N, Timmer CP, Weisbrod J (2007) Pathways out of poverty during an economic crisis: An empirical assessment of rural Indonesia. Working Paper No. 15, Center for Global Debelopment.

Pitoyo AJ (2010) Bina keluarga migran menuju sejahtera: Pemanfaatan produktif remitan, dalam Akes Penduduk Miskin Terhadap Kebutuhan Dasar. Yogyakarta: Pusat Studi Kependudukan dan Kebijakan UGM.

Sefriani (2013) Perlindungan HAM buruh migran tak berdokumen berdasarkan hukum perdagangan dan hukum HAM internasional. Jurnal Dinamika Hukum 13 (2):245-256.

Setyawati D (2013) Asset or commodities? Comparing regulations of placement and protection of migrant workers in Indonesian and the Philippines. ASEAS-Austrian Journal of South-East Asian Studies 6 (2):264-280.

Sugiyarto G \& Vargas-Silva C (2012) Effects of global crisis on remittance and poverty in Asia, dalam, Asia Development Bank, Global Crisis, Remittances and Poverty in Asia, The Philippines: ADB. 31-48.

Yamanaka K and Piper N (2005) Feminized migration in East and Southeast Asia. UNSRID.

Yazid S (2013) Indonesia's civil society in the age of democratization. NGO Responses on the Issue of Labour Migration, Baden-Baden: Nomos. 